\title{
Fluorescence and Circular Dichroism Studies with Hemocyanin from Taiwan Snails
}

\author{
Sung M. Wang, Min N. Chen, Zen C. Chung, Ji R. Tzou, \\ Norman C. $\mathrm{Li}^{1}$, and Yee-Hsiung Chen
}

SMW, MNC, ZCC, JRT, NCL. Department of Chemistry, National Tsing Hua University, Taiwan.-YHC. Institute of Biochemical Science, National Taiwan University and Institute of Biological Chemistry, Academia Sinica, Taipei

\begin{abstract}
Several derivatives of hemocyanin from Taiwan snails (Achatina fulica) have been prepared. The reconstituted protein $\left(\mathrm{R}-\mathrm{HcO}_{2}\right)$ has lower $\mathrm{Cu}$ content, lower circular dichroism intensity, and higher fluorescence intensity than native oxyhemocyanin $\left(\mathrm{HcO}_{2}\right)$. The $\mathrm{Co}$ (II) derivative $(\mathrm{CoHc})$ does not take up molecular oxygen and only $50 \%$ of the total sites for $\mathrm{Cu}$ in native hemocyanin is taken up by $\mathrm{Co}$. The halfapo derivative (half-apo-Hc) contains a single $\mathrm{Cu}$ per active site. Divalent cations quench the tryptophan fluorescence in the hemocyanin species and also quench the fluorescence from $\mathrm{Tb}^{3+}$ bound to the protein. The collisional quenching constants decrease in the order $\mathrm{Co}^{2+}>\mathrm{Mn}^{2+}>\mathrm{Ca}^{2+}$. The static component is negligible. For carboxy hemocyanin $(\mathrm{HcCO})$, fluorescence originates from a $\mathrm{Cu}(\mathrm{I}) \mathrm{CO}$ complex and was used to study reaction of $\mathrm{Hc} \mathrm{CO}$ with $\mathrm{CN}^{-}$.
\end{abstract}

\section{INTRODUCTION}

Hemocyanins, the copper-containing proteins that carry oxygen, are found in the hemolymph of many arthropods and molluscs. They bind oxygen in the ratio of one oxygen molecule for every two copper atoms. The protein, deep blue colored when oxygenated, becomes colorless when deoxygenated by passing $\mathrm{N}_{2}$, and the coppers in

\footnotetext{
Address reprint requests to Dr. Sung M. Wang, Department of Chemistry, National Tsing Hua University, Hsinchu, Taiwan 30043.

${ }^{1}$ On leave from Departments of Chemistry, Duquesne University, Pittsburgh, PA 15282 and Catholic University of America, Washington, DC 20064.
} 
deoxy hemocyanin are $\mathrm{Cu}(\mathrm{I})$ [1]. This paper describes studies on metal ion and cyanide interactions with several derivatives of Achatina fulica hemocyanin from Taiwan snails, from fluorescence and circular dichroism measurements. The following derivatives of hemocyanin were prepared: reconstituted $\left(\mathrm{R}-\mathrm{HcO}_{2}\right)$, cobalt $(\mathrm{CoHc})$, half-apo(half-apoHc), carboxy $(\mathrm{HcCO})$, apo(apoHc), and met (metHc).

The interactions between $\mathrm{CoHc}, \mathrm{R}-\mathrm{HcO}_{2}$, native oxyhemocyanin $\left(\mathrm{HcO}_{2}\right)$, or halfapo-Hc and divalent cations were studied by fluorescence measurements (excitation, $280 \mathrm{~nm}$; emission, $340 \mathrm{~nm}$ ). Fluorescence experiments (excitation, $295 \mathrm{~nm}$; emission, $543 \mathrm{~nm}$ due to protein-bound $\mathrm{Tb}^{3+}$ ) were carried out to determine whether the emission intensity at $543 \mathrm{~nm}$ may be used to monitor the interaction of added $\mathrm{TbCl}_{3}$ with hemocyanin and the effect of added divalent cations on the interactions. For $\mathrm{HcCO}$, the excitation wavelength was $295 \mathrm{~nm}$ and the observation wavelengths were 330 and $540 \mathrm{~nm}$. We found that the fluorescence emission intensity at $540 \mathrm{~nm}$ is an excellent probe for studying the interaction of $\mathrm{HcCO}$. $\mathrm{CoHc}, \mathrm{HcO}_{2}$, and $\mathrm{R}-\mathrm{HcO}_{2}$ were also studied by carrying out circular dichroism experiments.

\section{MATERIALS AND METHODS}

\section{Preparations}

Hemocyanin was prepared from the hemolymph of Taiwan snails and purified as previously described [2]. Protein concentration was determined spectrophotometrically by using $\epsilon_{280}(1 \%, 1 \mathrm{~cm}) 15.71$. The copper content was determined by neutron activation analysis (using the Tsing Hua University reactor) to be $0.24 \%$, and the minimal molecular weight of the protein that contains one dicopper active site was taken to be 53,000 . ApoHc was prepared by dialysis of $\mathrm{HcO}_{2}$ in $50 \mathrm{mM}$ Tris- $\mathrm{HCl}$ buffer (pH 8.0) against the same buffer that contained $10 \mathrm{mM} \mathrm{KCN}$ at $4^{\circ} \mathrm{C}$ for 3 days. It was then dialyzed against the buffer alone for 2 days with changes every $4 \mathrm{hr}$. With this procedure, $97 \%$ of the total copper was removed from the active site, and the apoHc showed no absorption at $345 \mathrm{~nm}$. Reconstituted $\mathrm{Hc}, \mathrm{R}-\mathrm{HcO}_{2}$, was prepared by treating the apoHc solution at $\mathrm{pH} 5.7$ for $24 \mathrm{hr}$ at $4^{\circ} \mathrm{C}$ in $\mathrm{N}_{2}$ atmosphere with an amount of $\mathrm{Cu}\left(\mathrm{CH}_{3} \mathrm{CN}\right)_{4} \mathrm{ClO}_{4}$ corresponding to twice the copper content of native $\mathrm{Hc}$ $[3,4] . \mathrm{R}-\mathrm{HcO}_{2}$ was dialyzed against $0.025 \mathrm{M}$ EDTA in $0.1 \mathrm{M}$ acetate buffer, pH 5.7, $\mathrm{N}_{2}$ atmosphere for $24 \mathrm{hr}$ and afterwards against the acetate buffer alone for 1 day. A copper content of $0.21 \%$ was found, corresponding to a reconstitution factor of $87.5 \%$. MetHc was prepared by treating $\mathrm{HcO}_{2}$ with $25 \mathrm{mM}$ azide in $0.1 \mathrm{M}$ sodium acetate buffer, pH 5.0 at $37^{\circ} \mathrm{C}$ [5]. The excess azide was removed by extensive dialysis against $0.1 \mathrm{M}$ acetate buffer, $\mathrm{pH} 5.7$.

The cobalt derivative of $\mathrm{Hc}(\mathrm{CoHc})$ was prepared by dialysis of apoHc against 50 $\mathrm{mM}$ Tris- $\mathrm{HCl}$ buffer ( $\mathrm{pH} \mathrm{8.0)}$, which contained $1 \mathrm{mM} \mathrm{CoCl}_{2}$ at $4^{\circ} \mathrm{C}$ for 4 days under $\mathrm{N}_{2}$ atmosphere followed by dialysis against Co-free buffer at pH 8.0 for 2 days. The resulting crude sample of $\mathrm{CoHc}$ was treated with Chelex 100 resin (40\% by volume, preequilibrated with the Tris- $\mathrm{HCl}$ buffer) to remove excess $\mathrm{Co}(\mathrm{II})$. A blue solution was obtained. The Co content in $\mathrm{CoHc}$ is $0.11 \%$, which corresponds to $49.4 \%$ of the total sites for $\mathrm{Cu}$ in native $\mathrm{Hc}$. The amount of residual $\mathrm{Cu}$ in $\mathrm{CoHc}$ is in the range $0.01 \%$ $0.02 \%$. It varies somewhat from preparation to preparation and depends partly on the duration of dialysis with $\mathrm{KCN}$ and $\mathrm{pH}$ in forming apoHc. The residual $\mathrm{Cu}$ constituted less than $0.1 \%$ of the total sites for $\mathrm{Cu}$ in native $\mathrm{Hc}$. $\mathrm{CoHc}$ does not bind $\mathrm{O}_{2}$ even under $\mathrm{O}_{2}$ atmosphere. Half-apo-Hc, colorless, was prepared by dialysis at $4^{\circ} \mathrm{C}$ of 
deoxyhemocyanin $(6 \mathrm{mg} / \mathrm{ml})$ against $\mathrm{N}_{2}$ saturated Tris- $\mathrm{HCl}$ buffer $\mathrm{pH} 8.0$ containing $3.8 \mathrm{mM} \mathrm{CN}^{-}$. In $10 \mathrm{hr}$, the Cu content had dropped from $0.24 \%$ to $0.13 \%$, indicating formation of half-apo-Hc. Himmelwright et al. [6] have previously shown that one copper can be selectively removed from the binuclear active site of Busycon, yielding a half-apo protein, and that the copper is $\mathrm{Cu}(\mathrm{I})$.

\section{Physical Measurement}

Fluorescence spectra were measured on a Hitachi MPF-4 fluorescence spectrophotometer operated at $25^{\circ} \mathrm{C}$. Circular dichroism measurements were performed on a Jasco J20 spectropolarimeter. The concentrations of $\mathrm{Cu}$ and $\mathrm{Co}$ in the hemocyanin derivatives were determined by use of inductively coupled plasma-atomic emission spectrometer.

\section{RESULTS AND DISCUSSION}

The quenching of fluorescence upon oxygen binding to hemocyanin has been traced to nonradiative electronic energy transfer from the originally excited trytophanyl residues to the $\mathrm{Cu} \cdots \mathrm{O}$ groups [2]. For $A$. fulica hemocyanin at $\mathrm{pH} 8.0$, the fluorescence intensities of native oxyhemocyanin $\left(\mathrm{HcO}_{2}\right)$, reconstituted oxyhemocyanin $\left(\mathrm{R}-\mathrm{HcO}_{2}\right)$, and cobalt hemocyanin $(\mathrm{CoHc})$ are $6.8,16.5$, and 44.1, respectively (in arbitrary units; excitation, $280 \mathrm{~nm}$; emission maxima at 324,323 , and $330 \mathrm{~nm}$, respectively, for $\mathrm{HcO}_{2}, \mathrm{R}-\mathrm{HcO}_{2}$, and $\mathrm{CoHc}$ ). Since the concentration of the $\mathrm{CuO}_{2} \mathrm{Cu}$ groups is higher in $\mathrm{HcO}_{2}$ than in $\mathrm{R}-\mathrm{HcO}_{2}(\mathrm{Cu}$ contents of $0.24 \%$ and $0.21 \%$, respectively), it is natural that the fluorescence intensity in $\mathrm{HcO}_{2}$ is less than in $\mathrm{R}$ $\mathrm{HcO}_{2}$. The active site of $\mathrm{CoHc}$ contains a single $\mathrm{Co}$ atom and no oxygen, so that of these three species of the protein, $\mathrm{CoHc}$ shows the greatest fluorescence intensity.

Divalent cations further quench fluorescence, as shown in Figure 1 for $\mathrm{CoHc}$. The quenching reaction between hemocyanin and $\mathrm{M}^{2+}$ can be described by the following:

$$
\mathrm{Hc}+\mathrm{M}^{2+} \underset{k_{-d}}{\stackrel{k_{d}}{\rightleftarrows}}\left(\mathrm{Hc} \cdots \mathrm{M}^{2+}\right)
$$

where $\left(\mathrm{Hc} \cdot \mathrm{M}^{2+}\right)$ is the complex formed by diffusional encounter between $\mathrm{Hc}$ and $\mathrm{M}^{2+}$ with rate constant $k_{d}$. The experimentally observed rate constant for the quenching reaction, $k_{q}$, is equal to $k_{d}$ when the efficiency of the quenching process is unity [8]. The collisional quenching process, equation (1), is usually described by the Stern-Volmer equation [9]:

$$
F_{0} / F=1+K_{\text {Sv }}\left[\mathrm{M}^{2+}\right]
$$

where $F_{0}$ and $F$ are the fluorescence intensities at an appropriate emission wavelength in the absence and presence of quencher $\left[\mathrm{M}^{2+}\right], K_{\mathrm{SV}}$ is the collisional quenching constant, which is equal to $k_{q} \tau_{0}$, and $\tau_{0}$ is the fluorescence lifetime in the absence of quencher. By plotting $F_{0} / F$ at the appropriate emission maxima vs. $\left[\mathrm{M}^{2+}\right]$, linear plots for $\mathrm{CoHc}, \mathrm{R}-\mathrm{HcO}_{2}$, and $\mathrm{HcO}_{2}$ were obtained. Figure 1 gives plots for $\mathrm{CoHc}$. The values of $K_{\mathrm{Sv}}$ for $\mathrm{Hc}=\mathrm{CoHc}, \mathrm{HcO}_{2}$, and $\mathrm{R}-\mathrm{HcO}_{2}$, and $\mathrm{M}^{2+}=\mathrm{Ca}^{2+}, \mathrm{Mn}^{2+}$, and $\mathrm{Co}^{2+}$, are listed in Table 1 .

A more complete treatment of the kinetics of the quenching reaction should include consideration of a "static" quenching process [8]. In a randomly distributed solution, the quencher and the chromophore molecules occasionally may come very close to 
FIGURE 1. Plots of $F_{0} / F$ vs. $\left[\mathrm{CaCl}_{2}\right],\left[\mathrm{MnCl}_{2}\right]$, and $\left[\mathrm{CoCl}_{2}\right]$ added to solutions containing $\mathrm{Co} \mathrm{Hc}(2.8$ $\mathrm{mg} / \mathrm{ml}) \mathrm{pH} 8.0$.

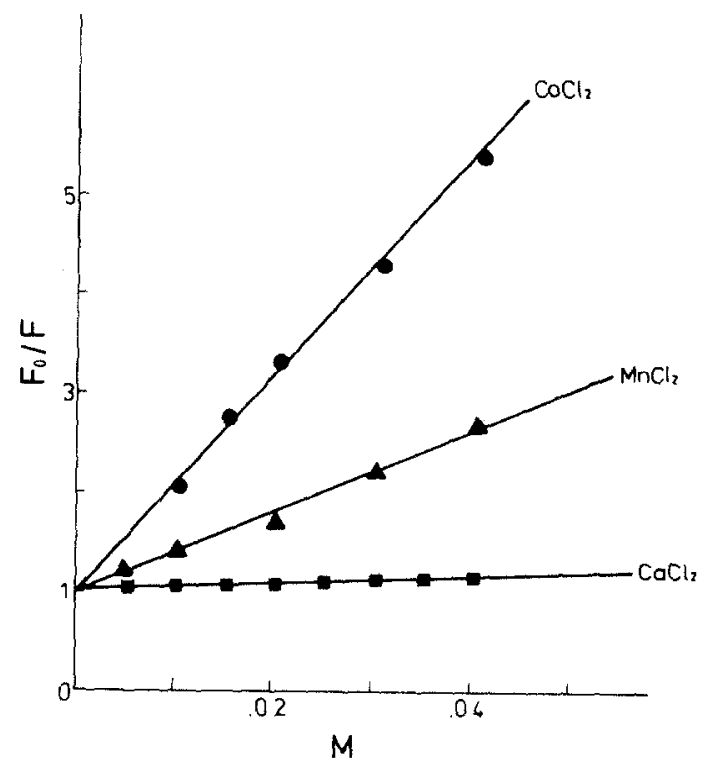

each other when the latter become excited. In this case, the probability for the reaction may become so high that quenching occurs instantaneously (statically). The kinetics of the quenching reaction include a collisional (characterized by $K_{\mathrm{SV}}$ ) and a static (characterized by $V$ ) component, and equation (2) becomes [8]

$$
\left.F_{0} / F=\left(1+K_{\text {SV }}\left[\mathrm{M}^{2+}\right]\right) e^{v_{1} \mathrm{M}^{2+}}\right]
$$

Since Figure 1 gives linear plots between $F_{0} / F$ and $\left[\mathrm{M}^{2+}\right], V$ must be very small and we need to consider only the collisional quenching by the cations.

Linear plots of $F_{0} / F$ vs. [M $\left.{ }^{2+}\right]$ are also obtained for solutions of half-apo-Hc at $\mathrm{pH}$ 8.0. The values of $K_{\mathrm{Sv}}$ are included in Table 1 . For the half-apo-Hc, the emission maximum is at $330 \mathrm{~nm}$ (excitation, $280 \mathrm{~nm}$ ).

On addition of $\mathrm{TbCl}_{3}$ to hemocyanin solution, three emission bands, due to proteinbound $\mathrm{Tb}^{3+}$, are observed at 490,543, and $590 \mathrm{~nm}$. Figure 2 gives plots of fluorescence intensity at $543 \mathrm{~nm}$ (excitation, $295 \mathrm{~nm}$ ) when $\mathrm{TbCl}_{3}$ is added to different hemocyanins, each at $1.2 \times 10^{-6} M$ at $\mathrm{pH} 6.5$, using piperazine-1,4-bis(2ethanesulfonic acid) salt (PIPES- $\mathrm{Na}_{2}$ ) as buffer. Fluorescence intensities in $\mathrm{Tb}^{3+}$. hemocyanins are in the order apoHc $>\mathrm{CoHc}>\mathrm{R}-\mathrm{HcO}_{2}>\operatorname{metHc}>$ native $\mathrm{HcO}_{2}$.

TABLE 1. Values of $K_{\mathrm{SV}}$ for $\mathrm{Hc}+\mathrm{M}^{2+}=$ $\left(\mathrm{Hc} \cdot \mathrm{M}^{2+}\right)$ at $\mathrm{pH} 8.0,25^{\circ} \mathrm{C}$

\begin{tabular}{lcrr} 
& $\mathrm{M}=\mathrm{Ca}^{2+}$ & $\mathrm{Mn}^{2+}$ & $\mathrm{Co}^{2+}$ \\
\hline $\mathrm{CoHc}$ & 4 & 44 & 110 \\
$\mathrm{HCO}_{2}$ & 2 & 10 & 54 \\
$\mathrm{R}_{\mathrm{HcO}}$ & 2 & 8 & 50 \\
$\mathrm{Half}-\mathrm{apo}-\mathrm{Hc}$ & 2 & & 68 \\
\hline
\end{tabular}




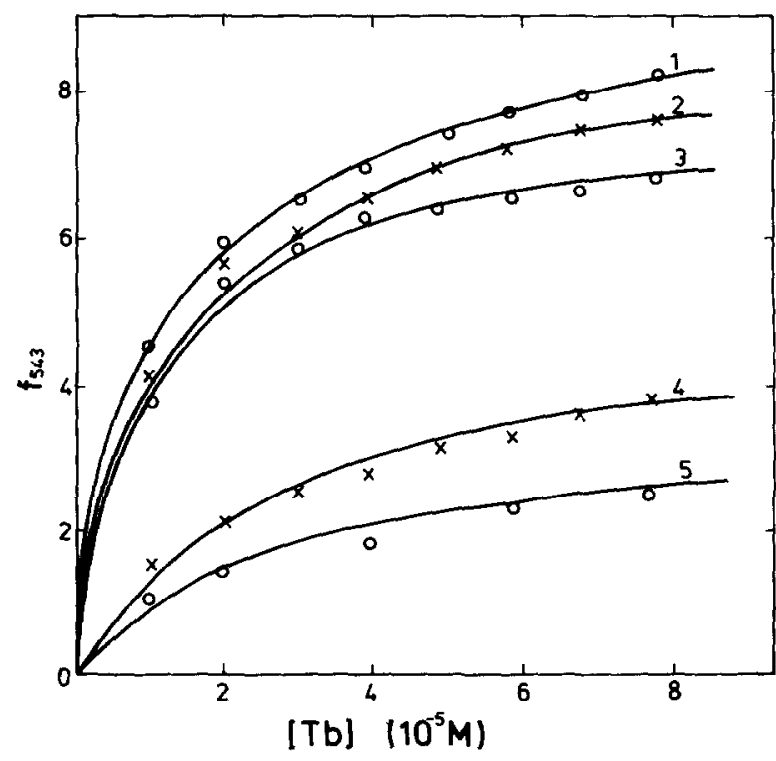

FIGURE 2. Fluorescence intensity at $543 \mathrm{~nm}$ (arbitrary units), $\mathrm{pH} 6.5$, as function of $\mathrm{Tb}^{3+}$ concentration added to various hemocyanins: 1 , apoHc; 2, $\mathrm{CoHc} ; 3, \mathrm{R}-\mathrm{HcO}_{2} ; 4$, metHc; $5, \mathrm{HcO}_{2}$ (Hc concn. $1.2 \times 10^{-6}$ $M)$.

In Figure 2, correction for the $\mathrm{Tb}^{3+}$ fluorescence intensity in the absence of hemocyanin is entirely negligible. ApoHc has both copper sites vacant. In the preparation of $\mathrm{CoHc}$, the amount of $\mathrm{Co}$ (II) introduced into apoHc reached only up to $50 \%$ of the total sites for $\mathrm{Cu}$ in the native Hc. The vacancies of 2 and 1 copper sites, respectively, in the active sites of apoHc and $\mathrm{CoHc}$, explains the order of fluorescence enhancements when $\mathrm{Tb}^{3+}$ is added to these two protein species. In metHc, both coppers are $\mathrm{Cu}$ (II), which is an effective fluorescence quencher. $\mathrm{HcO}_{2}$ contains both $\mathrm{Cu}(\mathrm{II})$ ions and, in addition, an $\mathrm{O}_{2}^{2-}$. A previous paper [10] has indicated that oxygen is an effective quencher of $\mathrm{Tb}^{3+}$ bound to Panulirus hemocyanin. In the present research the presence of dioxygen in native $\mathrm{HcO}_{2}$ causes this species to be the most effective fluorescence quencher, resulting in the lowest fluorescence intensity among the various hemocyanin species investigated.

Addition of $\mathrm{CaCl}_{2}, \mathrm{MnCl}_{2}$, or $\mathrm{CoCl}_{2}$ to a solution of hemocyanin containing $\mathrm{TbCl}_{3}$ causes a decrease in fluorescence at 490 and $543 \mathrm{~nm}$. The results for $\mathrm{HcO}_{2}$ are shown in Figure 3. These are plots of $F_{0} / F$ at $543 \mathrm{~nm}$ vs. $\left[\mathrm{Ca}^{2+}\right],\left[\mathrm{Mn}^{2+}\right]$, and $\left[\mathrm{Co}^{2+}\right]$, at pH 6.5, where $F_{0}$ and $F$ are fluorescence intensities for the $\mathrm{HcO}_{2}-\mathrm{TbCl}_{3}$ solution (Hc, 1.2 $\left.\times 10^{-6} \mathrm{M} ; \mathrm{Tb}^{3+}, 4 \times 10^{-5} \mathrm{M}\right)$ in the absence and presence of a divalent cation, respectively.

The interaction of a divalent cation, $\mathrm{M}^{2+}$, with $\mathrm{Tb}^{3+}$. Hc may be written

$$
\mathrm{Tb}^{3+} \cdot \mathrm{Hc}+\mathrm{M}^{2+} \underset{k_{-d}}{\stackrel{k_{d}}{\rightleftarrows}}\left(\mathrm{Tb}^{3+} \cdot \mathrm{Hc} \cdots \mathrm{M}^{2+}\right)
$$

Since the fluorescence intensity at $543 \mathrm{~nm}$ is due to the protein-bound $\mathrm{Tb}^{3+}$, equation (2) holds also for equation (4). Figure 3 shows linear plots of $F_{0} / F$ vs. [ $\left[\mathrm{M}^{2+}\right]$, with intercept equal to 1.0 , for $\mathrm{HcO}_{2}$. For other hemocyanin derivatives with $\mathrm{Tb}^{3+}$ concentrations varying from $2.4 \times 10^{-5} \mathrm{M}$ to $1.1 \times 10^{-4} \mathrm{M}$, our results show that 
FIGURE 3. Plots of $F_{0} / F$ at $543 \mathrm{~nm}$ vs. $\left[\mathrm{CaCl}_{2}\right],\left[\mathrm{MnCl}_{2}\right]$, and $\left[\mathrm{CoCl}_{2}\right]$ added to $\mathrm{HcO}_{2-}$ $\mathrm{TbCl}_{3}$ solution $\left(\mathrm{Hc}, 1.2 \times 10^{-6} \mathrm{M} ; \mathrm{Tb}^{3+}, 4 \times\right.$ $10^{-5} M$ ), at $\mathrm{pH} 6.5$.

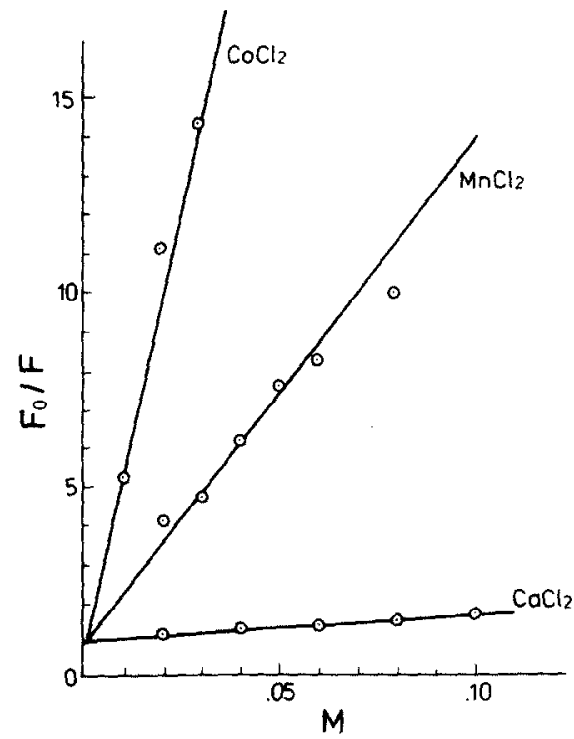

equation (2) is also valid for equation (4). The average values of $K_{\mathrm{Sv}}$ are given in Table 2.

In forming complexes, both $\mathrm{Ca}^{2+}$ and $\mathrm{Tb}^{3+}$ prefer oxygen-donor ligands (in proteins, $\mathrm{RCO}_{2}^{-}, \mathrm{RO}^{-}, \mathrm{C}=\mathrm{O}$ and $\mathrm{H}_{2} \mathrm{O}$ ), whereas $\mathrm{Co}^{2+}$ prefers nitrogen-donor ligands. Of the divalent cations listed in Tables 1 and $2, \mathrm{Co}^{2+}$ gives the largest $K_{\mathrm{SV}}$ values for all of the $\mathrm{Hc}$ species.

The values of $K_{\mathrm{SV}}$ for $\mathrm{Mn}^{2+}$ are smaller than for $\mathrm{Co}^{2+}$ (Tables 1,2). These are in the same order as the overall binding constants of histidine complexes: $\log K$ for $\mathbf{M n}$ histidine and Co-histidine complexes are 3.3 and 6.9 , respectively [11]. Since the metal ligands in the active sites of $\mathrm{Hc}$ are predominantly histidine [12], the higher $K_{\mathrm{SV}}$ for $\mathrm{Co}^{2+}$ over $\mathrm{Mn}^{2+}$ is reasonable.

The circular dichroism and absorption spectra of $\mathrm{CoHc}(\mathrm{pH} \mathrm{8.0)}$ are very similar to those reported for the Co derivative of squid hemocyanin [13]. The absorption of the $\mathrm{Co}$ (II) chromophore at $550-600 \mathrm{~nm}$ is very similar to the $1: 1$ cyanide complex of Co(II)-human carbonic anhydrase [14] and has been attributed to the transitions arising from a high-spin tetrahedral Co(II) center. The successful preparation of a halffilled Co(II) hemocyanin from the hemolymph of the squid, Sepioteuthis lessoniana,

TABLE 2. Values of $K_{\mathrm{SV}}$ for $\mathrm{Tb}^{3+} \cdot \mathrm{Hc}+\mathrm{M}^{2+}=$ $\left(\mathrm{Tb}^{3+} \cdot \mathrm{Hc} \cdots \mathrm{M}^{2+}\right)$ at $\mathrm{pH} 6.5,25^{\circ} \mathrm{C}$

\begin{tabular}{lcrc} 
Hemocyanin & $\mathrm{M}=\mathrm{Ca}^{2+}$ & $\mathrm{Mn}^{2+}$ & $\mathrm{Co}^{2+}$ \\
\hline Apo & 15 & 60 & 420 \\
$\mathrm{Met} \mathrm{Hc}$ & 15 & 140 & 820 \\
$\mathrm{Co} \mathrm{Hc}$ & 10 & 60 & 630 \\
$\mathrm{Hc} \mathrm{O}$ & 8 & 130 & 480 \\
$\mathrm{R}-\mathrm{HcO}_{2}$ & 15 & 80 & 460 \\
\hline
\end{tabular}


has been reported [13], so that the $A$. fulica Hc behaves like squid Hc. The preparation of 1-Co(II)-substituted Hc from Helix pomatia and Carcinus [15, 16] have also been reported. On the other hand, the amount of $\mathrm{Co}$ (II) introduced into horseshoe apohemocyanins reached essentially $100 \%$ of the total sites for copper ions in native hemocyanins [17]. A. fulica CoHc was kept in a dialysis bag (pH 8.0) under $\mathrm{O}_{2}$-atmosphere at room temperature, and the visible absorption band around $600 \mathrm{~nm}$ remained unchanged. This indicates that $\mathrm{CoHc}$ does not take up molecular oxygen at all, and may be explained by taking into account the structural restriction of the $\mathrm{Co}$ (II) binding which is tetrahedral [13]. The octahedral geometry would enable dioxygen binding as in the case of several $\mathrm{Co}$ (II)-dioxygen complexes of low molecular weights $[18,19]$.

The effects of $\mathrm{CO}$ on the luminescence properties of Helix pomatia $\alpha$-hemocyanin and Panulirus interruptus hemocyanin have been discussed [10]. These proteins, when saturated with $\mathrm{CO}$, show emission with maxima between 540 and $560 \mathrm{~nm}$, in addition to the tryptophan resonance at $340 \mathrm{~nm}$. The emission in the visible region originates from a fluorescent $\mathrm{Cu}(\mathrm{I})-\mathrm{CO}$ complex, and this emission is interpreted as charge-transfer luminescence. With $A$. fulica hemocyanin, the excitation wavelength is $295 \mathrm{~nm}$; emission for $\mathrm{HcCO}$ is $540 \mathrm{~nm}$. A peak also occurs at $330 \mathrm{~nm}$. However, the oxy, deoxy, and met hemocyanins also give fluorescence maxima at $330 \mathrm{~nm}$ (with varying intensities because of different extents of quenching tryptophan fluorescence), whereas only $\mathrm{HcCO}$ gives a fluorescence peak at $540 \mathrm{~nm}$ in addition to an emission maximum at $330 \mathrm{~nm}$. With addition of $\mathrm{CN}^{-}$, the intensity at $330 \mathrm{~nm}$ increases because $\mathrm{Cu}$ is removed from the protcin in forming apoHc. The $540-\mathrm{nm}$ peak decreases because inorganic $\mathrm{Cu}$ does not bind $\mathrm{CO}$. The result is illustrated in Figure 4, giving the fluorescence spectra of (a) $\mathrm{HcCO}$ and (b) $\mathrm{HcCO}+\mathrm{KCN}(0.0016 M)$, spectra taken $45 \mathrm{~min}$ after preparation of solutions. At $2.5 \mathrm{hr}$ after preparation, the $\mathrm{HcCO}$ peak at $540 \mathrm{~nm}$ decreased to zero, while the 330-nm peak continued to increase. On standing overnight, the $330-\mathrm{nm}$ peak was increased only slightly. During fluorescence

FIGURE 4. Fluorescence spectra of $\mathrm{HcCO}$ in the absence (a), and presence (b) of $0.0016 M$ $\mathrm{KCN}, \mathrm{pH} 8.0$.

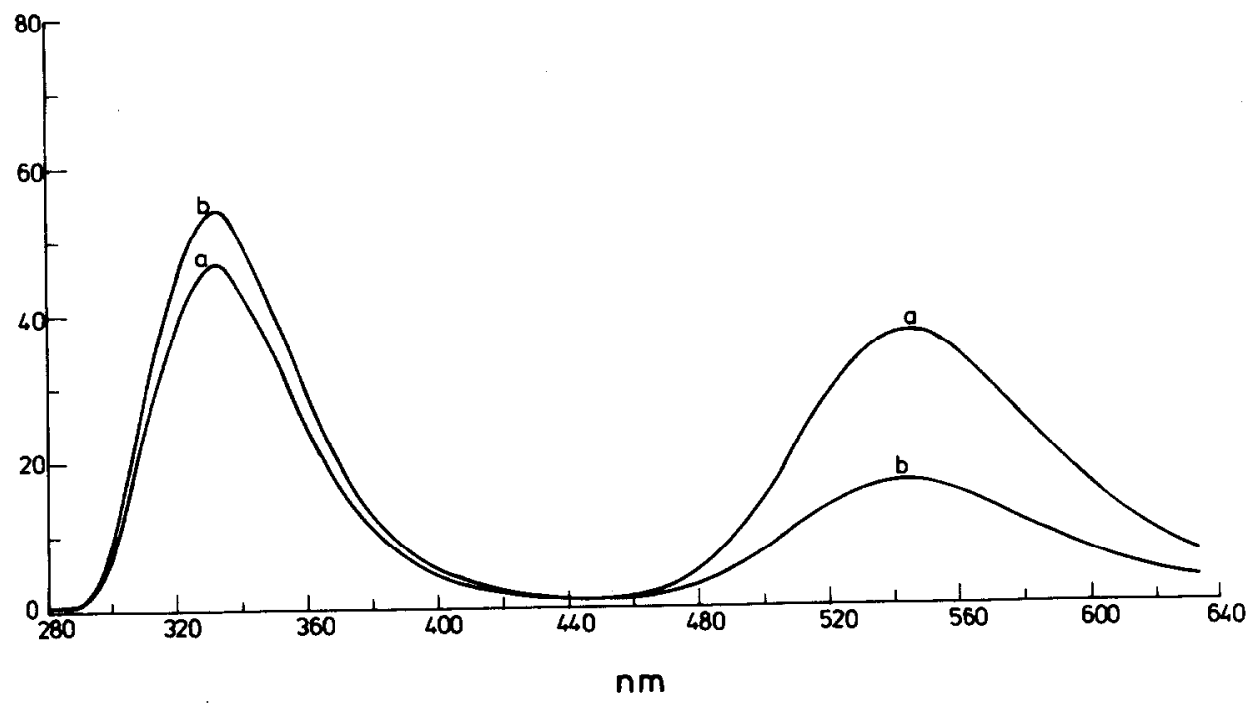




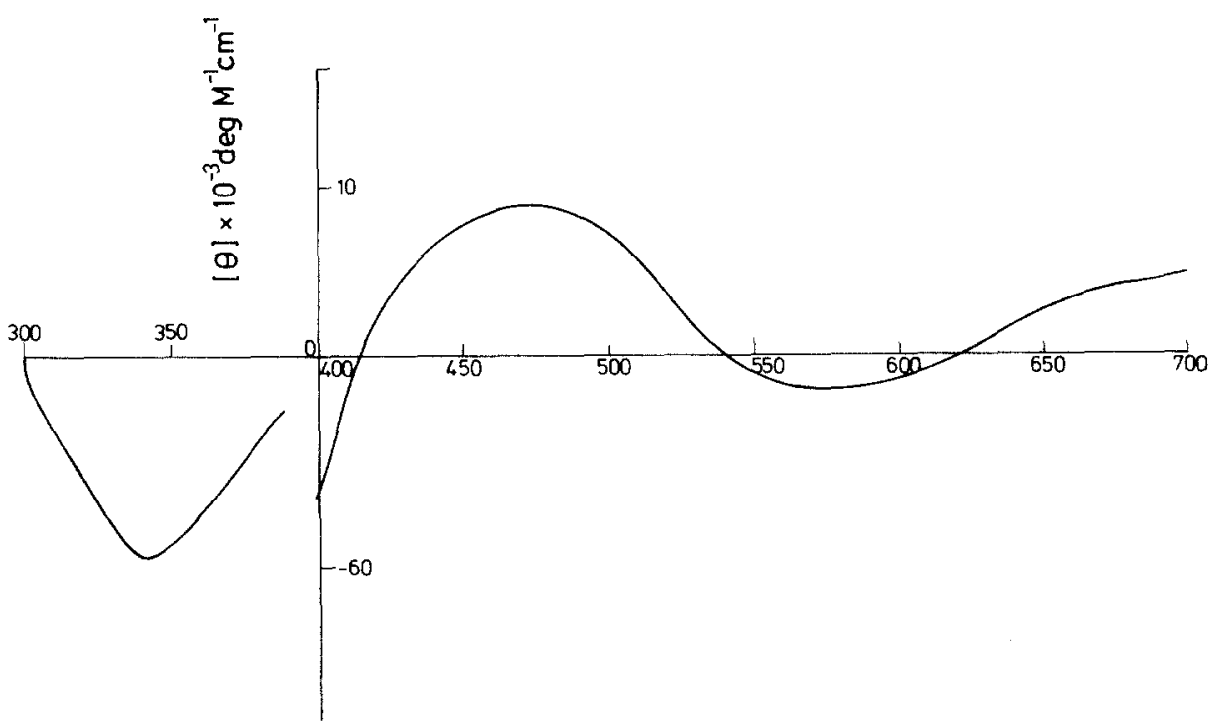

FIGURE 5. CD spectrum of native $\mathrm{HcO}_{2}\left(2.34 \times 10^{-4} M\right)$, pH 8.0.

measurements, $\mathrm{HcCO}$ samples were exposed to air. Although $\mathrm{O}_{2}$ is a quencher, separate experiments have shown that the effect of dissolved $\mathrm{O}_{2}$ in solution on protein fluorescence intensity is negligible.

The CD spectrum of native $\mathrm{HcO}_{2}\left(2.35 \times 10^{-4} M\right) 300-700 \mathrm{~nm}$ is shown in Figure 5. A. fulica $\mathrm{HcO}_{2}$ exhibits two positive bands at 470 and $700 \mathrm{~nm}$ and one negative band at $575 \mathrm{~nm}$, and one intense negative band around $340 \mathrm{~nm}$. The spectra are similar to those of squid [11]. The CD spectrum of $\mathrm{R}-\mathrm{HcO} 2\left(2.39 \times 10^{-4} \mathrm{M}\right)$ also exhibits maxima at 470 and $700 \mathrm{~nm}$, and negative bands at 575 and $340 \mathrm{~nm}$. The intensities are somewhat smaller: the values of $[\theta]$ at 340 and $470 \mathrm{~nm}$ for $\mathrm{R}-\mathrm{HcO}_{2}$ are $-25.2 \times 10^{3}$ and $2.96 \times 10^{3} \mathrm{deg} M^{-1} \mathrm{~cm}^{-1}$, respectively, compared to corresponding values of $-59.5 \times 10^{3}$ and $8.5 \times 10^{3} \mathrm{deg} M^{-1} \mathrm{~cm}^{-1}$ for native $\mathrm{HcO}_{2}$. For both $\mathrm{HcO}_{2}$ and $\mathrm{R}-$ $\mathrm{HcO}_{2}$, in the presence of $0.02 \mathrm{M} \mathrm{KCN},[\theta]$ becomes zero in the entire wavelength range. This is because apoHc is formed, as has been found for Busycon and Limulus apohemocyanins. The smaller values of $[\theta]$ for $\mathrm{R}-\mathrm{HcO}_{2}$ compared to $\mathrm{HcO}_{2}$ are in line with the lower $\mathrm{Cu}$ content and therefore a smaller number of oxygenated active sites of the reconstituted protein.

\section{CONCLUDING REMARKS}

The very first report on hemocyanin from Taiwan snails was published in 1979 [2]. This paper describes further properties of various derivatives prepared from this species: reconstituted hemocyanin, cobalt, met, apo, and half-apo-Hc. The reconstituted oxyhemocyanin has a lower copper content, lower circular dichroism intensity, and higher fluorescence intensity than native oxyhemocyanin. Cobalt hemocyanin does not take up molecular oxygen, and only $50 \%$ of the total sites for $\mathrm{Cu}$ in native $\mathrm{Hc}$ is occupied by $\mathrm{Co}$. Half-apo-Hc contains a single copper in the active site, compared to no copper in apoHc and two coppers in $\mathrm{HcO}_{2}$. Himmelwright et al. [6] have previously shown that one copper can be selectively removed from the binuclear active site of Busycon, yielding a half-apo-protein, and that the copper is $\mathrm{Cu}(\mathrm{I})$. Divalent cations 
quench the tryptophan fluorescence of various $\mathrm{Hc}$ species, including the half-apo-Hc, and quench the fluorescence due to $\mathrm{Tb}^{3+}$ bound to the various $\mathrm{Hc}$ species. The values of the collisional quenching constant decrease in the order $\mathrm{Co}^{2+}>\mathrm{Mn}^{2+}>\mathrm{Ca}^{2+}$, and the static component of quenching is negligible. For $\mathrm{HcCO}$, the observed emission at $540 \mathrm{~nm}$ (excitation, $295 \mathrm{~nm}$ ) originates from a fluorescent $\mathrm{Cu}(\mathrm{I}) \mathrm{CO}$ complex, and was used to study reaction of $\mathrm{CN}^{-}$with $\mathrm{HcCO}$.

This work was supported by the National Science Council, ROC. The authors also thank Miss Sin Tak Chu for her very capable assistance with instrumentation.

\section{REFERENCES}

1. R. Lontie and L. Vanquickenborne, in Metal Ions in Biological Systems, H. Sigel, Ed., Marcel Dekker, New York, 1974, Vol. 3, p. 183.

2. J. T. Chen, S. T. Shen, C. S. Chung, H. Chang, S. M. Wang, and N. C. Li, Biochemistry 18, 3097 (1979).

3. R. Lontie, V. Blaton, M. Albert, and B. Peters, Arch. Int. Physiol. Biochim. 73, 150 (1965).

4. S. M. Wang, M. N. Chen, J. M. Tsay, C. S. Chung, and N. C. Li, J. Chinese Chem. Soc. 32, 355 (1985).

5. R. Witters and R. Lontie, FEBS Lett. 60, 400 (1975).

6. R. S. Himmelwright, N. C. Eickman, and E. I. Solomon, Biochem. Biophys. Res. Commun. 81, 243 (1978).

7. N. Shaklai and E. Daniel, Biochemistry 9, 564 (1970).

8. M. R. Eftink and C. A. Ghiron, Biochemistry 15, 672 (1976).

9. J. B. Birks, Photophysics of Aromatic Molecules, Wiley-Interscience, New York, 1970 , pp. 433-447.

10. H. A. Kuiper, F. A. Alessandro, E. Antonini, and M. Brunori, FEBS Lett. 99, 317 (1979).

11. A. E. Martell and R. M. Smith, Critical Stability Constants, Plenum, New York, 1974, Vol. 1, p. 61.

12. J. M. Brown, L. Powers, B. Kincaid, J. A. Larrabee, and T. G. Spiro, J. Am. Chem. Soc. 102, 4210 (1980).

13. S. Suzuki, W. Mori, J. Kino, Y. Nakao, and A. Nakahara, J. Biochem. 88, 107 (1980).

14. J. E. Coleman and R. V. Coleman, J. Biol. Chem. 247, 4718 (1972).

15. R. Witters and R. Lontie, Life Chem. Rep. Suppl. 1, 285 (1982).

16. B. Salvato, A, Ghiretti-Magaldi, and F. Ghiretti, Biochemistry 13, 4778 (1974).

17. S. Suzuki, J. Kino, and A. Nakahara, Bull. Chem. Soc. Jpn. 55, 212 (1982).

18. R. D. Jones, D. A. Summerville, and F. Basolo, Chem. Rev. 79, 139 (1979).

19. W. P. Schaefer, B. T. Huie, M. G. Kurilla, and S. E. Ealick, Inorg. Chem. 19, 340 (1980).

Received July 21, 1986; accepted November 19, 1986 